\section{Australian Journal of \\ Crop Science}

\title{
Assessment of damage caused by the spider mite Mononychellus planki (McGregor) on soybean cultivars in South America
}

\author{
Jonas Andre Arnemann* ${ }^{1}$, Rubens Alex Fiorin ${ }^{2}$, Jerson Vanderlei Carus Guedes ${ }^{1}$, Henrique Pozebon ${ }^{1}$, \\ Rafael Paz Marques ${ }^{1}$, Clerison Regis Perini ${ }^{1}$, Lindolfo Storck ${ }^{3}$
}

${ }^{1}$ Departamento de Defesa Fitossanitária, Universidade Federal de Santa Maria, Campus de Camobi, Santa Maria, RS, 97105-900, Brasil

${ }^{2}$ Nufarm Indústria Química e Farmacêutica S.A, Rua Safira, 257, Camobi, Santa Maria, RS, Brasil

${ }^{3}$ Programa de Pós-graduação em Agronomia, Universidade Federal de Santa Maria, Campus de Camobi, Santa Maria, RS, 97105-900, Brasil

\section{*Corresponding author: jonasarnemann@gmail.com; jerson.guedes@smail.ufsm.br}

\begin{abstract}
The aim of this study was to quantify the reduction in grain productivity caused by tetranychid mites in different soybean genotypes. For this purpose, two experiments were carried out in two different experimental sites, one with 20 and another with 25 soybean cultivars. The sites had distinct soil features and were chosen to verify the influence of local conditions in the manifestation of intrinsic soybean plant resistance to spider mites. The experimental design was of randomized blocks with subdivided plots and four replications. The effects of cultivars were assessed in plots $5 \times 25 \mathrm{~m}$ and yield reduction was investigated in subplots regarding presence and absence of tetranychid mites. The presence of mites on each cultivar was checked weekly after the emergence of soybean plants, until the detection of its occurrence. To evaluate the mite population, 25 leaflets of the upper stratum and 25 of the lower stratum of plants were randomly collected from a $20 \mathrm{~cm}^{2}$ area to quantify the density of mites. The results showed that predominant species was Mononychellus planki (McGregor) (>90\%). The other species such as Tetranychus urticae (Koch), Tetranychus ludeni (Zacher), Tetranychus gigas (Pritchard) and Tetranychus desertorum (Banks) were also observed. The population of mites and grain yield loss differed significantly depending on the soybean cultivar. The average reduction in soybean productivity in both experiments was $483 \mathrm{~kg}$ of soybean/hectare, corresponding to an average reduction of $20 \%$ of the productive potential of the cultivars evaluated. The spider mites can cause a great damage to soybean cultivar. Therefore, growers must regularly scout for its presence in the field, applying control measures as soon as the level of spider mites significantly increases.
\end{abstract}

Keywords: Glycine max, tetranychid mites, economic damage, yield loss.

Abbreviations: AE_Acid equivalent; AI_active ingredient; ASL_above sea level.

\section{Introduction}

Soybean is one of the main agricultural crops in Brazil, with a production of 95.4 thousand tons in the 2015/16 crop in a cultivated area of 33.2 million ha (CONAB, 2017). Some limiting factors to soybean crop yield include pest insects and mites. The first occurrence of mites in Brazil has been recorded from soybeans in Rio Grande do Sul State (Flechtmann, 1972), severe attacks have been observed in different crops and different regions of Brazil (Guedes et al., 2007; Roggia, 2010), requiring the application of acaricide for their control.

Factors such as acreage increase, introduction of genetically modified varieties and increasing use of insecticides and fungicides (Roggia, 2010) have been indicated as possible causes for the increase in populations of phytophagous mites (Guedes et al., 2007). This highlights the need for the adoption of an integrated management of mites by identifying, quantifying and assessing their populations as well as analyses of damages, aiming at the definition for the time of control.

Temperature, air humidity, precipitation and other weather events are considered the main co-factors that modulate the population dynamics of phytophagous mites (Guedes et al., 2007; Roggia et al., 2008). However, Arnemann et al. (2015) indicated that plant factors are also important, as different soybean genotypes present different tolerance levels. These variations can be attributed to the production of secondary metabolites, the morphology of leaf surface and the presence of natural enemies (Boom et al., 2003). Another possibility is the variation caused by the production of defense compounds that act to repel organisms harmful to the plant, called induced defense (War et al., 2012).

Mites that infest soybean plants tend to focus on the abaxial surface of the leaflet, where they feed by puncturing the cells and sucking the exudated liquid. This removal of 
cytoplasmic content reduces the chlorophyll content and increases water losses in the cells, which impairs the photosynthesis ability of the leaflet, compromising the normal plant development (Flechtmann, 1972). In addition, soybean plants attacked by mites show accelerated maturation, reduction of grain yield mainly due to the lower average weight of seeds. Severe attacks at the start of the crop cycle can completely compromise the production (Pedigo and Tollefson, 1997).

The characteristic symptoms of mite attacks in soybeans are the presence of white or yellow spots on the leaf surface, which evolve tanning and necrosis, leading to premature drop of leaflets, accelerated maturation and higher percentage of small grains (Dehghan et al., 2009). The occurrence of pest intensifies after stages R4-R5 of the crop (Arnemann et al., 2015). In North America, Gray (2006) reported that control measures must be adopted considering the presence of $20-25 \%$ of the soybean leaves with symptoms of attack in the growing season (discoloration) and $10-15 \%$ in the reproductive period. To date, only one study (Suekane et al., 2012) suggested the economic injury level for mite control in soybeans, which was conducted in a greenhouse with the mite species Tetranychus urticae (Koch) and only in one soybean cultivar. Among the alternative methods of control included in the Integrated Pest Management (IPM) approach, the use of genetic resistance has been emerged as a valuable tool in the control of mites, since several studies have reported significant differences in population density and plant susceptibility to mite attack among different soybean cultivars (Sedaratian et al., 2009; Dehghan et al., 2009; Razmjou et al., 2009). Genetic tolerance of plants to arthropods is also affected by abiotic factors; and thus, may vary according to the environmental conditions to, which the plant is subjected (Fancelli and Vendramim, 2008).

Considering the increasing occurrence of mites in the soybean crop and the lack of information on the damage they cause, this study aimed to quantify, yield loss caused by tetranychid mites in different soybean cultivars under field conditions as well as classification of these cultivars according to their susceptibility to mite attack.

\section{Results and Discussion}

\section{Mite species}

The species of phytophagous mites identified in the experiments were Mononychellus planki (McGregor), Tetranychus urticae (Koch), Tetranychus ludeni (Zacher), Tetranychus gigas (Pritchard) and Tetranychus desertorum (Banks). Guedes et al. (2007) and Roggia et al. (2008) identified these species as relevant in soybean culture infestations. The predominant species $(>90 \%)$ in the samples was $M$. planki. The influence of mite predators in the mite population dynamics was not significant, since its occurrence was observed only in a few samples. Therefore, this variable was not subjected to statistical analysis. Low occurrence of mite predators is a common aspect of soybean crops, being attributed mainly to unfavorable management practices, such as the use of broad-spectrum pesticides (e.g. herbicides and fungicides, Roggia et al., 2008; Roggia, 2010).

\section{Population density of mites}

The results of the analysis of variance indicate significant difference $(p<0.05)$ on population density of mites between the cultivars evaluated in both locations (Table 1 ), showing that each cultivar was affected differently upon development and density of mite populations. These variations are directly associated to the biology of the mite species, the climatic conditions and the capacity of genetic resistance of plant (Dehghan et al., 2009), which depends on morphological aspects of the leaf surface (Elden, 1997), production of defense compounds (Ali, 1999) and nutritional value of the vegetal tissue (Brown et al., 1991).

The smallest populations of mites were observed in cultivar FUNDACEP 57 RR (average 0.75 mites $/ 20 \mathrm{~cm}^{-2}$ ) in Experiment I and SYN 1059 RR in Experiment II (average 5.74 mites $/ 20 \mathrm{~cm}^{-2}$ ). Cultivar BMX Energy RR presented the highest densities of mites in both experiments, with 11.69 mites $/ 20 \mathrm{~cm}^{-2}$ in Experiment $I$ and 25.31 mites $/ 20 \mathrm{~cm}^{-2}$ in Experiment II. This is corroborating with the results obtained by Arnemann (2013), who classified this genotype as one of the most vulnerable to mite infestation. The Scott and Knott test was used to constitute seven classes of cultivars according to the occurrence of mites, highlighting the significant effect of cultivars on fluctuation of mite populations.

Phenological stage of the soybean crop was also interfered with the population dynamics of mites, since the development of the plant in short periods tends to favor the configuration of resistance (Arnemann, 2013). Sedaratian et al. (2009) investigated the occurrence of $T$. urticae in 14 soybean genotypes and found significant difference in population density of mites and resistance levels between the materials evaluated. Similar results were reported from Egypt (Sawires et al., 1990), EUA (Brown et al., 1991) and Iran (Razmjou et al., 2009).

\section{Experimental sites}

In general, the occurrence of mites in the cultivars in Experiment I was lower than observed in Experiment II. Later sowing date in Experiment II can be pointed as one aspect responsible for this difference, since other abiotic factors such as rainfall and humidity did not interfere significantly on the mite population development, and acted equally on the different cultivars. The weather condition in Experiment I was highly favorable to mite development, having long periods of low rainfall and low relative air humidity, as previously suggested by Guedes et al. (2007) and Roggia et al. (2008). However, no significant effect of such climatic conditions was observed on the population density of mites in the different genotypes (Supplementary Figure 1 and 2). In experiments conducted with different soybean cultivars in two crop seasons (2009/10 and 2010/11), Siqueira (2011) also observed significant variations in populations of $M$. planki between the two periods, but did not find any correlation with climatic factors, since weather conditions were similar in both seasons.

Regarding the influence of phenological stages of the soybean plant in the population development of mites, Arnemann et al. (2015) reported that infestation tends to start at the phenological stage V5 for most cultivars, increasing in density until the plants reach stage R5. In 
cotton, significant reductions in yield are also linked to early infestations, when associated with high rates of population increase and longer time of development (Wilson, 1993).

\section{Effects of spider mite attack on grain yield}

The results of the analysis of variance for grain yields show a significant effect $(p<0.01)$ for the cultivars due to the treatment with acaricide in both locations (Table 2). It demonstrates that the grain yield of each cultivar was differed significantly between sprayed and unsprayed subplots, but not in relation to the other cultivars. Therefore, general averages of all the cultivars were used to quantify yield loss, defined as the percentage difference between yield averages of the area treated with acaricide versus the untreated area.

Yield loss of soybean due to mite attack was $435 \mathrm{~kg} \mathrm{ha}^{-1}$ (23\%) and $531 \mathrm{~kg} \mathrm{ha}^{-1}(18 \%)$ for Experiments I and II, respectively, although the occurrence of mites was higher in Experiment II, with an average population of 17.67 mites per $20 \mathrm{~cm}^{-2}$. These results highlight the importance of mite control in soybean and the definition of a control level, avoiding significant losses due to the attack of mites.

The observed yield loss due to the lack of control ranged from $7.52 \%$ (cultivar A $6411 \mathrm{RG}$ ) to $44.45 \%$ (cultivar TMG 7161 RR) in Experiment I and from 5.68\% (cultivar NS 6636 RR) to $29.83 \%$ (cultivar NA 4990 RG) in Experiment II. The comparison of data from Tables 1 and 2 indicates that the cultivars with the highest density of mite do not have the largest yield loss. The Pearson correlation coefficient calculated for these two variables (number of mites versus yield loss) was 0.23 in Experiment I and 0.27 in Experiment II, both classified as low according to Shimakura (2006). Therefore, it was not possible to establish a direct linear correlation between the two variables.

\section{Classification of cultivar susceptibility}

Although resistance of cultivars to attack by mite is difficult to quantify due to the complexity of factors involved (Arnemann, 2013), the relationship between population of mite and yield loss allows a classification of cultivars in terms of their susceptibility to mite damage. In this study, we present a classification of cultivar susceptibility considering the average population of mites and yield loss (Figure 1 and 2). The use of Tocher's opmitization method allowed the clustering of the soybean genotypes in homogenous groups, constituting six classes of cultivars in Experiment I (São Sepé) and eight classes in Experiment II (Santa Maria). These classes were ranked according to their relative susceptibility to mite attack. Cultivars that presented high yield losses under low population of mites were classified as highly susceptible to damage by mites. Conversely, cultivars with low yield losses in conditions of high infestation were classified as having high tolerance to mite attack, withstanding high densities of mites without losing grain yield.

There was a significant variation in the results between the two experiments, and most cultivars showed higher susceptibility to damage by mites in Experiment 1 (Table 2). Weather conditions did not have a direct effect on the population dynamics of the pest, but may have affected the development of the plants, causing differences in the levels of natural resistance expressed by the different cultivars in the two experimental sites. The crops were rain-fed in both sites, and the periods of low rainfall recorded in Experiment I as well as low air humidity (Supplementary Figure 1) may cause the plants to undergo a state of hydric stress, increasing its vulnerability to mite attacks (EstebanesGonzalez and Rodriguez-Navarro, 1991).

The later sowing date of Experiment II favored the occurrence of higher population densities of tetranychid mites in this site, but also triggered the manifestation of resistance in these plants, since a shorter period of development increases the chances of resistance in soybean (Fenner, 1998) and cotton (Wilson, 1993). Additionally, brief periods of exposure to mite feeding can induce higher levels of resistance in some cultivars, as mite-resistance is linked to cumulative lipid peroxidation of the tissues and loss of carotenoids and chlorophyll in the plant (Hildebrand et al., 1986).

The correlation coefficient between the two sites was 0.47 for the variable number of mites (moderate correlation) and 0.06 for the variable yield loss (very weak correlation), indicating that the manifestation of intrinsic plant resistance is highly dependent to the local conditions. Therefore, the presented classification of cultivars according to their susceptibility to mite attack (Table 3 ) is valid for the local regions where the experiment was conducted.

Potential resistance of soybean to tetranychid mites was addressed by Sedaratian et al. (2011), who analyzed life table parameters of two-spotted spider mite Tetranychus urticae (Koch) on 14 soybean genotypes, evaluating susceptibility through the rates of population increase. However, the study was conducted under experimental conditions and with cultivars adapted to the Iranian environment, and since local aspects are key factors in the expression of genetic resistance (Fancelli and Vendramim, 2008). Classification of genotypes and environment must be taken into the account for particular environmental condition of the region, to which the study or cultivation is aimed, as well as using genotypes with local commercial importance. Furthermore, few studies have proposed control levels based on the capacity of the mites to cause damage under field conditions, according to their population in each soybean cultivar.

\section{Yield loss and economic injury level}

In the 2005/06 crop, in areas with and without chemical control of spider mites such as in São Sepé, Rio Grande do Sul State, the tetranychid attacks caused losses of $270 \mathrm{~kg}$ ha

${ }^{1}$ on average in soybean production (Arnemann et al., 2006). Studies in the south half of the Rio Grande do Sul State during the 2004/05 crop showed that in outbreaks of mite incidence in crops, the plant wilt and yield losses of up to $50 \%$ may occur (Silva and Gassen, 2005). Carlson (1969) conducted an experiment that evaluated the chemical control of mites in soybean by applying different acaricides in California and reported yield losses of up to $90 \%$ in untreated areas, compared with areas where the chemical control was used. For Klubertanz (1994), this loss may reach $60 \%$ of grain yield. 
Table 1. Average number of spider mites in $20 \mathrm{~cm}^{-2}$ per leaflet, in soybean cultivars in the municipalities of São Sepé e Santa Maria, RS, Brazil, during the 2011/2012 season

\begin{tabular}{|c|c|c|}
\hline Soybean cultivar & Experiment I & Experiment II \\
\hline A 6411 RG & $7.72 b^{*}$ & $16.55 c$ \\
\hline A 7321 RG & $2.44 f$ & $13.14 \mathrm{c}$ \\
\hline BMX Ativa RR & $2.67 f$ & $25.27 a$ \\
\hline BMX Energia RR & $11.69 a$ & $25.31 a$ \\
\hline BMX Potência RR & $2.87 f$ & $22.98 a$ \\
\hline BMX Turbo RR & $5.03 d$ & $20.34 b$ \\
\hline Don Mario 5.8i (Apolo RR) & $2.52 f$ & $14.84 c$ \\
\hline FPS Urano RR & $4.52 d$ & $24.43 a$ \\
\hline FUNDACEP 57 RR & $0.75 \mathrm{~g}$ & $7.80 \mathrm{~d}$ \\
\hline NA 4990 RG & $4.03 \mathrm{e}$ & $18.53 b$ \\
\hline NA 5909 RG & $1.12 \mathrm{~g}$ & $21.66 b$ \\
\hline NK 7059 RR (V-max RR) & $0.78 \mathrm{~g}$ & $11.93 \mathrm{c}$ \\
\hline NS 4823 RR & $4.85 d$ & $10.82 d$ \\
\hline NS 5858 RR & $6.25 c$ & $20.87 b$ \\
\hline NS 6636 RR & $3.47 \mathrm{e}$ & $16.86 \mathrm{c}$ \\
\hline ROOS Camino RR & $11.01 \mathrm{a}$ & $24.42 a$ \\
\hline SYN 1059 RR (V-top RR) & $1.86 f$ & $5.74 d$ \\
\hline SYN 1161 RR & $3.09 \mathrm{e}$ & $14.74 \mathrm{c}$ \\
\hline SYN 1163 RR & $3.46 \mathrm{e}$ & $24.41 a$ \\
\hline TMG 7161 RR & $8.62 b$ & $18.60 \mathrm{~b}$ \\
\hline FUNDACEP 59 RR & - & $8.93 d$ \\
\hline NS 7100 RR & - & $13.91 \mathrm{c}$ \\
\hline SYN 1157 RR & - & $18.53 b$ \\
\hline SYN 1158 RR & - & $17.42 \mathrm{~b}$ \\
\hline 08 ca905023 & - & $23.82 \mathrm{a}$ \\
\hline General average & 4.44 & 17.67 \\
\hline $\mathrm{CV}(\%)$ & 93.11 & 42.5 \\
\hline
\end{tabular}

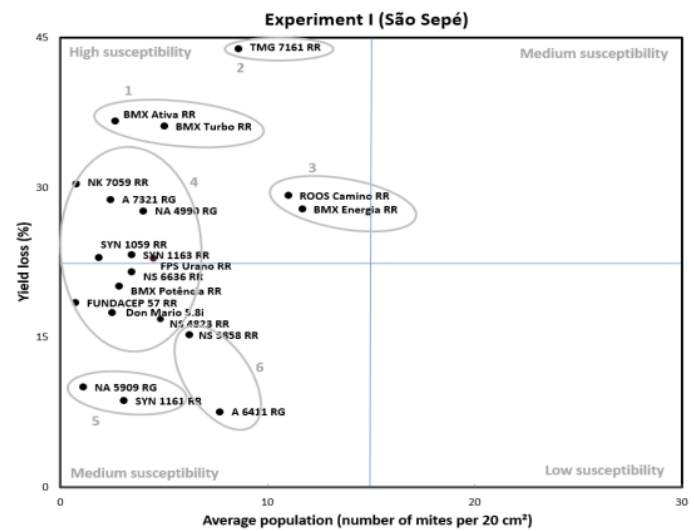

Fig 1. Relationship between mite population and yield loss in soybean cultivars grouped by Tocher's optimization method, in the municipality of São Sepé, during the 2011/2012 season.

Table 2. Grain yield $\left(\mathrm{kg} \mathrm{ha}^{-1}\right)$ of soybean cultivars in relation to mite control, in the municipalities of São Sepé and Santa Maria, RS, Brazil, during the $2011 / 2012$ season.

\begin{tabular}{|c|c|c|c|c|c|c|}
\hline \multirow[b]{2}{*}{ Soybean cultivar } & \multicolumn{3}{|c|}{ Experiment I } & \multicolumn{3}{|c|}{ Experiment II } \\
\hline & With control & Without control & Yield loss (\%) & With control & Without control & Yield loss (\%) \\
\hline A 6411 RG & 1303.36a* & $1205.30 \mathrm{~b}$ & 7.52 & $2795.00 a$ & $2056.66 \mathrm{~b}$ & 26.42 \\
\hline A 7321 RG & $2437.97 a$ & $1736.19 \mathrm{~b}$ & 28.79 & $3291.25 a$ & $2631.66 \mathrm{~b}$ & 20.04 \\
\hline BMX Ativa RR & $1677.18 a$ & $1062.49 \mathrm{~b}$ & 36.65 & $2420.83 a$ & $1749.58 b$ & 27.73 \\
\hline BMX Energia RR & $2225.30 a$ & $1606.50 \mathrm{~b}$ & 27.81 & 2817.91a & $2168.33 b$ & 23.05 \\
\hline BMX Potência RR & $2372.99 a$ & $1896.46 \mathrm{~b}$ & 20.08 & $3290.83 a$ & $2807.08 b$ & 14.70 \\
\hline BMX Turbo RR & $2048.33 a$ & $1308.19 b$ & 36.13 & $3416.25 a$ & $2863.33 b$ & 16.18 \\
\hline Don Mario Apolo RR & $2211.31 a$ & $1825.03 b$ & 17.47 & $2901.25 a$ & $2277.91 b$ & 21.49 \\
\hline FPS Urano RR & $1936.03 a$ & $1492.11 b$ & 22.93 & $2148.33 a$ & $1639.58 b$ & 23.68 \\
\hline FUNDACEP 57 RR & 1993.93a & $1626.25 b$ & 18.44 & 2557.91a & $2205.83 b$ & 13.76 \\
\hline NA 4990 RG & $1789.74 a$ & $1295.18 b$ & 27.63 & $1916.66 a$ & $1345.00 \mathrm{~b}$ & 29.83 \\
\hline NA 5909 RG & $2032.05 a$ & $1829.00 \mathrm{~b}$ & 9.99 & $2866.25 a$ & $2382.50 \mathrm{~b}$ & 16.88 \\
\hline NK 7059 RR & $1900.25 a$ & $1324.24 b$ & 30.31 & $3138.33 a$ & $2732.50 \mathrm{~b}$ & 12.93 \\
\hline NS 4823 RR & $1552.78 \mathrm{a}$ & $1292.06 b$ & 16.79 & $3213.33 a$ & $2635.83 b$ & 17.97 \\
\hline NS 5858 RR & $1490.87 a$ & $1263.57 \mathrm{~b}$ & 15.25 & $3553.75 a$ & $2513.33 b$ & 29.28 \\
\hline NS 6636 RR & $1108.18 a$ & $869.80 \mathrm{~b}$ & 21.51 & $3222.91 a$ & $3040.00 \mathrm{~b}$ & 5.68 \\
\hline ROOS Camino RR & $1840.06 a$ & $1303.23 \mathrm{~b}$ & 29.17 & $3008.70 a$ & $2598.33 b$ & 13.64 \\
\hline SYN 1059 RR & $1741.34 a$ & $1341.36 \mathrm{~b}$ & 22.97 & $3056.66 a$ & $2840.83 b$ & 7.06 \\
\hline SYN 1161 RR & 1901.76a & $1737.24 b$ & 8.65 & 2959.58a & $2477.91 b$ & 16.27 \\
\hline SYN 1163 RR & $1806.76 a$ & $1387.24 b$ & 23.22 & $3348.33 a$ & $2868.75 b$ & 14.32 \\
\hline TMG 7161 RR & $1654.77 a$ & $919.27 b$ & 44.45 & $3267.50 a$ & $2524.16 \mathrm{~b}$ & 22.75 \\
\hline FUNDACEP 59 RR & - & - & - & $2377.50 a$ & $1825.00 \mathrm{~b}$ & 23.24 \\
\hline NS 7100 RR & - & - & - & 2949.16a & $2432.50 \mathrm{~b}$ & 17.52 \\
\hline SYN 1157 RR & - & - & - & $3247.50 a$ & $2621.66 b$ & 19.27 \\
\hline SYN 1158 RR & - & - & - & $3347.50 a$ & $3063.33 b$ & 8.49 \\
\hline 08 ca905023 & - & - & - & $3142.08 a$ & $2675.00 \mathrm{~b}$ & 14.87 \\
\hline General average & 1851.25 & 1416.04 & 23.29 & 2970.21 & 2439.06 & 18.28 \\
\hline CV (\%) & 24.05 & 6.97 & - & 12.73 & 6.35 & - \\
\hline
\end{tabular}




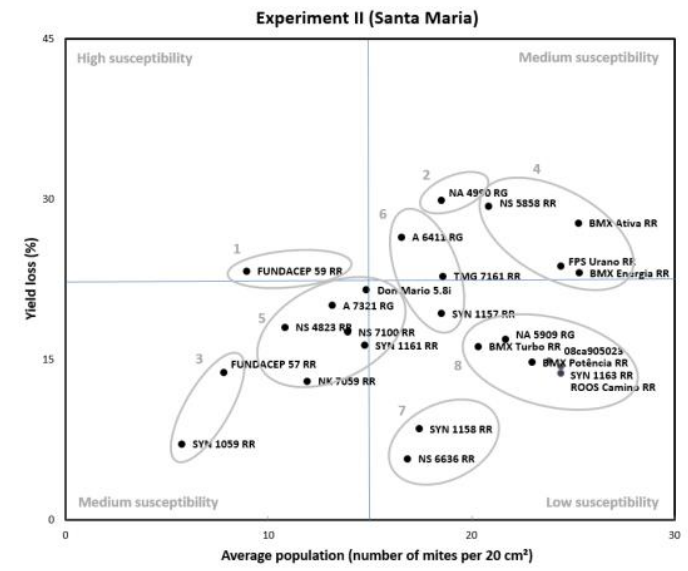

Fig 2. Relationship between mite population and yield loss in soybean cultivars grouped by Tocher's optimization method, in the municipality of Santa Maria, during the 2011/2012 season.

Table 3. Classes of cultivars clustered by Tocher's optimization method and ranked according to their susceptibility to the attack of spider mites, in the municipalities of São Sepé and Santa Maria, RS, Brazil, during the 2011/2012 season.

\begin{tabular}{lll}
\hline Susceptibility & Class & Soybean cultivars \\
\hline $\begin{array}{l}\text { São Sepé } \\
\text { High }\end{array}$ & 1 & BMX Ativa RR, BMX Turbo RR \\
$\begin{array}{l}\text { High } \\
\text { High }\end{array}$ & 2 & TMG 7161 RR \\
High/Medium & 3 & BMX Energia RR, ROOS Camino RR \\
& 4 & A 7321 RG, BMX Potência RR, Don Mario 5.8i, FPS Urano RR, Fundacep 57 RR, NA 4990 RG, NK 7059 RR, NS 4823 RR, NS \\
Medium & 5636 RR, SYN 1059 RR, SYN 1163 RR \\
$\begin{array}{ll}\text { Medium } \\
\text { Santa Maria }\end{array}$ & 6 & NA 5909 RG, SYN 1161 RR \\
High & 1 & A 6411 RG, NS 5858 RR \\
Medium & 2 & \\
Medium & 3 & Fundacep 59 RR \\
Medium & 4 & NA 4990 RG \\
Medium & 5 & Fundacep 57 RR, SYN 1059 RR \\
Medium/Low & 6 & BMX Ativa RR, BMX Energia RR, FPS Urano RR, NS 5858 RR \\
Low & 7 & A 7321 RG, Don Mario 5.8i, NK 7059 RR, NS 4823 RR, NS 7100 RR, SYN 1161 RR \\
Low & 8 & A 6411 RG, SYN 1157 RR, TMG 7161 RR \\
& NS 6636 RR, SYN 1158 RR \\
\hline
\end{tabular}

Ruthes et al. (2007) reported a reduction of $23.33 \%$ of soybean productive potential in a condition when mites were not controlled in soybean. This reduction was similar to the average was observed in the present study in the São Sepé experiment, where the unsprayed subplots presented a reduction of $23.29 \%$ of the productivity potential of the cultivars under an average population of 4.44 mites per 20 $\mathrm{cm}^{-2}$. For two-spotted spider mites ( $T$. urticae), Suekane et al. (2012) proposed an economic injury level of $15.8 \%$ of chlorosis symptoms in leaflets, based on the value of US\$11.00/60 kg of soybean and control cost of US\$16.00/ha. Considering that plant resistance has been recognized as a fundamental tool for integrated pest management programs (Zehnder et al., 2007), the quantification of yield damage under field conditions and evaluation of resistance levels on different genotypes provide valuable information for the management of spider mites in soybean. Accordingly, further attention should be devoted to the influence of abiotic factors in the population dynamics of mites, since local conditions affect significantly the expression of plant resistance and may cause variations in the cultivar performance between different sites.

\section{Materials and Methods}

\section{Plant materials and experimental design}

Two experiments were conducted in the 2011/12 crop, one in the municipality of São Sepé (Experiment I) and another in the municipality of Santa Maria (Experiment II), both in the state of Rio Grande do Sul, Brazil. The experiment design was randomized blocks, with subdivided plots and four replicates. Each installment of $5 \times 25 \mathrm{~m}$ was seeded with a different soybean cultivar (Supplementary Table 1), where half of the plot received acaricide applications and the other half remained without application. Experiment I was conducted from December 2011 to May 2012, in an area located $30 \circ 18^{\prime} 41^{\prime \prime} S$ and $53 \circ 31^{\prime} 42^{\prime \prime} \mathrm{W}$, at $175 \mathrm{~m}$ a.s.l. The soil had a predominant sandy texture with medium to low chemical fertility, according to the soil analysis conducted. Twenty soybean cultivars (Supplementary Table 1) were sown on December 6, 2011, using the no-till system, directly onto the straw with a density of 30 seeds $\mathrm{m}^{-2}$. Experiment II was conducted from January to March 2012, in the experimental site of the Federal University of Santa Maria UFSM, in the municipality of Santa Maria (29-45'52"S and 53⒋' ' $^{\prime \prime} \mathrm{W}$, at $95 \mathrm{~m}$ a.s.I.), Rio Grande do Sul State, Brazil. The physical soil features was characterized as a medium clay soil with higher chemical fertility compared to Experiment I. Twenty-five soybean cultivars (Supplementary Table 1) were sown on January 16,2012 , using a density of 30 seeds $\mathrm{m}^{-2}$.

The genotypes used in both experiments were chosen due to their importance in the current scenario of the soybean culture in southern Brazil, which was evaluated according to the frequency of use of these cultivars by the growers. Sowing was carried out under a normal pest free condition, with the subsequent infestation by mites occurring naturally. The plants were grown under rain-fed condition in both sites. The weather conditions (rainfall, temperature and air 
humidity) were similar in the two sites (Supplementary Figure 1 and 2).

\section{Plant phenology}

Soybean phenology was assessed according to the scale proposed by Ritchie et al. (1982) and adapted by Yorinori (1996), which breaks the plant cycle into two phases: (1) vegetative phase consisting of stages (VC) from emergence to the opening of cotyledons; (V1) first node, unifoliate open leaves; (V2) second node, first open trefoil; (Vn) until the last node with open trefoil, before flowering; and (2) the reproductive phase, composed of stages (R1) beginning of flowering up to $50 \%$ of plants with one flower; (R2) full flowering, most racemes with open flowers; (R3) end of flowering, pods up to $1.5 \mathrm{~cm}$ long; (R4) most pods in the top third measuring 2-4 cm; (R5.1) grains visible to the touch with $10 \%$ of filling; (R5.2) most pods with $11-25 \%$ of grain filling; (R5.3) most pods with $26-50 \%$ of grain filling; (R5.4) most pods with $51-75 \%$ of grain filling; (R5.5) most pods with $76-100 \%$ of grain filling; (R6) pods with $100 \%$ of grain filing and green leaves; (R7.1) beginning until $50 \%$ of yellowing of the leaves and beans; (R7.2) yellowing of $51-75 \%$ of the leaves and beans; (R7.3) more than $75 \%$ of the leaves and yellow beans; (R8.1) beginning until $50 \%$ of defoliation; (R8.2) more than $50 \%$ of defoliation; and (R9) maturation point of the crop.

\section{Conduction of study}

In both experiments, $300 \mathrm{~kg} / \mathrm{ha}$ of NPK fertilizer (nitrogen, phosphorus and potassium) were applied in the sowing with a 10-20-20 formulation. The management of weeds in postemergence stage $\mathrm{V} 3$ of all cultivars was made with the application of $1,040 \mathrm{~g}$ of acid equivalent (a.e.) $\mathrm{ha}^{-1}$ of glyphosate (Crucial, Nufarm, Maracanaú, CE, Brazil). For the management of pests and diseases at early stage, the seeds were treated with $25 \mathrm{~g}$ of active ingredient (a.i.) $\mathrm{ha}^{-1}$ of fipronil (Belure, Basf, São Paulo, SP, Brazil) and $1.25+0.5 \mathrm{~g}$ a.i. ha ${ }^{-1}$ of fludioxinil + metalaxyl-M (Maxim XL, Syngenta Crop Protection, São Paulo, SP, Brazil). For the control of defoliating caterpillars, $10 \mathrm{~g}$ a.i. ha $^{-1}$ of chlorantraniliprole (Premio, DuPont, São Paulo, SP, Brazil) were used at two stages: when most cultivars were at the phenological stage V4 (first application) and at stage V7 (second application). The insecticide imidacloprid (105 g a.i. ha ${ }^{-1}$ ) (Nuprid, Nufarm, Maracanaú, CE, Brazil) was applied at stages R4 and R5.3 of the cultivars for the management of stinkbugs and thrips. In addition, during the reproductive stage of the cultivars, three applications of fungicide were made for disease control. The applications were made when most cultivars were at R1, R4 and R5.4 stages. The fungicides used were composed of azoxystrobin ( $60 \mathrm{~g}$ a.i. $\left.\mathrm{ha}^{-1}\right)+$ cyproconazole $(24$ g a.i. ha $^{-1}$ ) (Priori + Alto 100, Alamos, Porto Alegre, RS, Brazil).

For the control of mites in treated subplots, three applications of acaricide abamectin $\left(9 \mathrm{~g}\right.$ a.i. ha $\left.{ }^{-1}\right)$ were carried out. The first application was made when the first cultivar was at reproductive stage (R1). The second and third applications were performed at stages R4 and R5.4, respectively, considering the cultivar at the most advanced cycle at the time of evaluation of the phenological stage. After the pre-spray check, weekly samplings were carried out after the first application of acaricide in the treated subplots to verify the effectiveness of the acaricide treatment and eventually determining the need for new applications.

\section{Traits measured}

In both sprayed and unsprayed subplots, mites were sampled weekly, from stage V5 until the end of the cycle of the cultivars (Supplementary Tables 2, 3). The population density of mites was determined in each subplot with random collection of 25 leaflets completely expanded from the middle stratum and 25 leaflets of the higher stratum of the plants. The leaflets were packed in paper bags, identified, stored in a cooler with ice and transported to the Laboratory for the Integrated Pest Management of UFSM (LabMIP), where they were kept under refrigeration (approximately $8^{\circ} \mathrm{C}$ ) until the total count of mites. Following the methodology proposed by Storck et al. (2012), the number of mites (eggs, immatures and adults) of each leaflet was counted in an area of $20 \mathrm{~cm}^{2}(4 \mathrm{~cm}$ base by $5 \mathrm{~cm}$ toward the leaflet apex) with the aid of stereoscopic microscope (40x magnifying). For the identification of mite species, microscope slides were mounted in Hoyer medium with different morphological types found in the samples and analyzed under optical microscope with phase contrast at the Brazilian Agricultural Research Corporation - Soybean (Embrapa- Soja).

The average number of mites was calculated considering the evaluations, in which at least one of the cultivars showed an average population greater than five mites per $20 \mathrm{~cm}^{-2}$ in the subplot that was not treated with acaricide. In Santa Maria, data from five evaluations were used, which carried out on Mar 9, Mar 16, Mar 24, Apr 3 and Apr 11, 2012, while in São Sepé, data from three evaluations conducted on Feb 29, Mar 7 and Mar 14, 2012 were used. In both experiments the grain yield (kilograms of soybean grain per hectare) was determined by harvesting of a central area of $10 \mathrm{~m}^{2}$ in each subplot with humidity correction to $13 \%$. Yield loss for each cultivar caused by mite attack was calculated by the percentage difference between the average yields in subplots sprayed with acaricide versus average yields in subplots unsprayed.

\section{Statistical analysis}

The analysis of variance for figures of grain yield and average number of mites in leaflets of soybean plants of both experiments was made. The means were compared by Scott and Knott $(p \leq 0.05)$ with the use of logarithmic transformation of data. The Pearson correlation coefficient was also calculated for the same variables. Tocher's optimization method using distance matrix (Rao, 1952) was applied to cluster the cultivars in homogenous groups and rank them according to their susceptibility to mite attack. The software "Genes" (Cruz, 2013) was used for the statistical analyses. The weekly samples carried out in weeks 1-11 for Experiment I (São Sepé) and 1-10 for Experiment II (Santa Maria) composed the subplots.

Since the analysis of variance requires data (in this case, number of mites per plot) normally distributed with homogeneous variation, we applied the Taylor Power Law (Taylor, 1961) to identify the appropriate transformation of 
the dependent variable $(y)$. As the slopes $(b)$ found were 1.56 and 1.66 for São Sepé and Santa Maria, respectively, it was concluded that the logarithmic transformation would be more appropriate for this case. Given the presence of null values, the transformation in $(y+1)$ was applied.

\section{Conclusion}

In this experiment, the average loss in soybean productive potential was $20 \%$ due to mite attacks, with minimum losses of $5.68 \%$ and a maximum of $44.45 \%$. This corresponded to an average reduction in grain yield of $483 \mathrm{~kg}$ of soybean/ha. The population of tetranychid mites varied significantly (1) between soybean cultivars, showing different resistance levels of plants to infestation, and (2) between the sites evaluated, showing the influence of local factors on population dynamics of this pest. It is possible to classify soybean cultivars according to their susceptibility to attacks of tetranychid mites, indicating that growers need to choose the soybean cultivars that are genetically less vulnerable to losses.

\section{Acknowledgements}

We thank all the people who helped during the experiments, particularly highlight the involvement of Alessandro Fiorentini, Caroline Huth, Clérison Perini, Cristiano De Carli, Leonardo Burtet and Lucas Stefanelo.

\section{References}

Ali NA (1999) Soybean leaf aging influencing the preference and non-preference to Tetranychus urticae (Koch), with reference to certain cultivars. Assiut J Agric Sci. 30: 91-96.

Arnemann JA, Guedes JVC, Roggia S, Sturmer GR, Bonadiman $R$, Santos JC Dos (2006) Efeito do controle químico de ácaros fitófagos no rendimento da soja. In: Jornada Acadêmica Integrada, 21, Universidade Federal de Santa Maria, Santa Maria, Brazil.

Arnemann JA (2013) Densidade e flutuação populacional de ácaros fitófagos em cultivares de soja. Master thesis, Universidade Federal de Santa Maria, Santa Maria, Brazil.

Arnemann JA, Fiorin RA, Perini CR, Storck L, Curioletti LE, Nachman G, Guedes JV (2015) Density and growth rates of spider mites in relation to phonological stages of soybean cultivars in Brazil. Exp Appl Acarol. 67: 423-440.

Boom CEM van den, Beek TA van, Dicke M (2003) Differences among plant species in acceptance by the spider mite Tetranychus urticae Koch. J Appl Entomol. 127: 177-183.

Brown GC, Nurdin F, Rodriguez JG, Hildebrand DF (1991) Inducible resistance of soybean (var. Wiliams) to twospotted spider mite (Tetranychus urticae Koch). J Kansas Entomol Soc. 64: 388-393.

Carlson E (1969) Spider mites on soybeans: injury and control. Calif Agric. 23: 16-18.

CONAB (2017). Companhia nacional de abastecimento: séries históricas. Available in: <http://www.conab.gov.br/conteudos.php?a=1252et=2eP agina_objcmsconteudos=2\#A_objc $>$. Accessed on 13 July 2017.
Cruz CD (2013) Genes - a software package for analysis in experimental statistics and quantitative genetics. Acta Sci Agron. 35(3): 271-276.

Dehghan MS, Allahyari H, Saboori A,Nowzari J, Naveh VH (2009) Fitness of Tetranychus urticae Kock (Acari: Tetranychidae) on different soybean cultivars: biology and fertility life-tables. Int J Acarol. 35: 341-347.

Elden TC (1997) Influence of soybean lines isogenic for pubescence type on two spotted spider mite (Acarina: Tetranychidae) development and feeding damage. I Entomol Sci. 32: 96-302.

Estébanes-Gonzalez ML, Rodríguez-Navarro SI (1991) Observaciones sobre algunos ácaros de las familias Tetranychidae, Eriophyidae, Acaridae y Tarsonemidae (Acari), en hortalizas de México. Folia Entomol Mex. 83: 199-212.

Fancelli M, Vendramim JD (2008) Resistência de plantas a insetos. Available $<$ http://www.portaldoagronegocio.com.br/conteudo.php? id=23709>. Accessed on 25 Nov 2011.

Fenner M (1998) The phenology of growth and reproduction in plants. Perspect Plant Ecol Syst. 1: 78-91.

Flechtmann CHW (1972) Ácaros de importância agrícola. Nobel, São Paulo, Brazil.

Gray M (2006) Two spotted spider mite infestations in soybean intensify as drought conditions persist. Available in: $\quad$ <http://bulletin.ipm.illinois.edu/print.php?id=354>. Accessed on 25 Nov 2011.

Guedes JVC, Navia D, Lofego AC, Dequech STB (2007) Ácaros associados à cultura da soja no Rio Grande do Sul. Neotrop Entomol. 32: 288-293.

Hildebrand DF, Rodriguez JG, Brown GC, Luu KT, Volden CS (1986) Peroxidative responses of leaves in two soybean genotypes injured by two-spotted spider mites (Acari: Tetranychidae). J Econ Entomol. 79: 1459-1465.

Klubertanz TH (1994) Two spotted spider mite. In: Higley LG, Boethel DJ (eds) Handbook of soybean insect pests. Entomological Society of America, Lanham, MD, USA.

Pedigo L, Tollefson J (1997) Two-spotted spider mites on soybean. Crop Manag. 478(20): 158-159.

Rao RC (1952) Advanced statistical methods in biometric research. John Wiley \& Sons, New York, USA.

Razmjou J, Tavakkoli H, Fallahi A (2009) Effect of soybean cultivar on life history parameters of Tetranychus urticae Koch (Acary: Tetranychidae). J Pest Sci. 82: 89-94.

Ritchie SW, Hanway JJ, Thompson HE (1982) How a soybean plant develops. Available in $<$ https://lib.dr.iastate.edu/cgi/viewcontent.cgi?referer=htt ps://www.google.com.br/\&httpsredir=1\&article $=1050 \& c 0$ ntext=specialreports $>$. Accessed on: 18 June 2018.

Roggia S, Guedes JVC, Kuss RCR, Arnemann JA, Návia D (2008) Spider mites associated to soybean in Rio Grande do Sul, Brazil. Pesq Agropecu Bras. 43: 295-301.

Roggia S (2010) Caracterização de fatores determinantes dos aumentos populacionais de ácaros tetraniquídeos em soja. PhD thesis, Universidade de São Paulo, Piracicaba, Brazil.

Ruthes E, Micheli A, Silva OC da, Freitas J de, Schipanski CA (2007) Eficiência de inseticidas/acaricidas no controle do ácaro verde, Mononychellus planki, na cultura da soja. In: Reunião de Pesquisa de Soja da Região Central, 39: 92-95. Embrapa Soja, Campo Grande, Brazil. 
Sawires ZR, Taha HA, Abdalla ST (1990) Biological and ecological studies on Tetranychus arabicus and relative susceptibility of seventeen soybean genotypes to infestation. Agric Res Rev. 68: 17-24.

Sedaratian A, Fathipour Y, Moharramipour S (2009) Evaluation of resistance in 14 soybean genotypes to Tetranychus urticae (Acari: Tetranychidae). J Pest Sci. 82: 163-170.

Sedaratian A, Fathipour Y, Moharramipour S (2011) Comparative life table analysis of Tetranychus urticae (Acari: Tetranychidae) on 14 soybean genotypes. Insect Sci. 18: 541-553.

Shimakura SE (2006) Interpretação do coeficiente de correlação. Available in: <http://leg.ufpr.br/ silvia/CE003/node74.html>. Accessed on: 19 July 2017.

Silva MTB, Gassen D (2005) Ácaros em soja. Rev Plantio Direto. 104: 1-5.

Siqueira F (2011) Biologia e flutuação populacional de Mononychellus planki (McGregor) (Acari: Tetranychidae) em cultivares de soja Glycine max (I.) Merr. e impacto do imidacloprido em aspectos biológicos do adulto. PhD Thesis, Universidade Federal do Paraná, Curitiba, Brazil.
Storck L, Fiorin RA, Cargnelutti Filho A, Guedes JVC (2012) A sampling procedure for quantifying mites in soybeans. Exp Appl Acarol. 57: 117-126.

Suekane R, Degrande PE, Melo EP de, Bertoncello TF, Lima Junior LS de, Kodama C (2012) Damage level of the twospotted spider mite Tetranychus urticae Koch (Acari: Tetranychidae) in soybeans. Rev Ceres. 59: 77-81.

Taylor LR (1961) Aggregation, variance and the mean. Nature. 189: 732-735.

War AR, Paulraj MG, Ahmad T, Buhroo AA, Hussain B, Ignacimuthu S, Sharma HC (2012) Mechanisms of plant defense against insect herbivores. Plant Signal Behav. 7(10): 1306-1320.

Wilson LJ (1993) Spider mites (Acari: Tetranychidae) affect yield and fiber quality of cotton. J Econ Entomol. 86: 566585.

Yorinori JT (1996) Cancro da haste da soja: epidemiologia e controle. Available

in:

<https://www.infoteca.cnptia.embrapa.br/infoteca/bitstre am/doc/460380/1/14.pdf>. Accessed on: 19 Mar 2016.

Zehnder G, Gurr GM, Kuhne S, Wade MR, Wratten SD, Wyss E (2007) Arthropod pest management in organic crops. Annu Rev Entomol. 52: 57-80. 